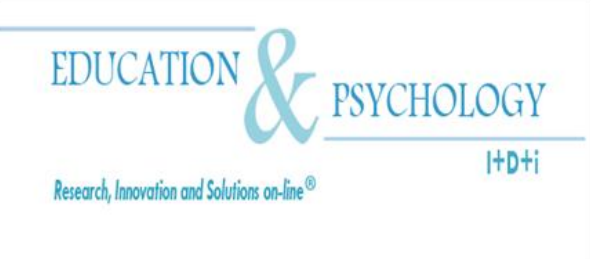

\title{
Gender and Achievement Differences in Secondary Students' Verbal Self-Concepts: A Closer Look beyond Bivariate Comparison
}

\author{
Günter Faber $^{1}$ \\ ${ }^{1}$ Institute of Educational Psychology, Leibniz Universität Hannover
}

Germany

Correspondence: Günter Faber. Leibniz Universität Hannover, Institute of Educational Psychology, Schloßwender Str.1, D-30159 Hannover. Germany. E-mail: faber@psychologie.uni-hannover.de

(C) Education \& Psychology I+D+i and Editorial EOS (Spain) 


\section{Abstract}

Introduction. Against the background of contradictory research findings in the field the present study aimed at unraveling the structural complexities of gender differences in secondary students' verbal self-concepts and, thus, analyzing possible gender $\times$ achievement interaction effects in the L1 German and L2 English language subject. According to an internal distress perspective significantly depressed self-concept scores for the female learners, in particular, at the low achievement level were assumed.

Method. Data were gathered in a sample of 256 ninth grade students from German inner-city grammar schools. For measuring students' L1 and L2 self-concept two subject-specific scales were administered. For measuring their achievement in each language subject teacher competence ratings as well as (self-reported) marks were used.

Results. With respect to the L1 German language subject, only a significant main effect of the achievement variable was found. Neither a gender effect nor an achievement $\times$ gender interaction could be demonstrated. Therefore, interindividually existing self-concept differences in favor of the female learners appeared to largely reflect their better achievement in the native language subject. With respect to the L2 language subject, likewise a significant main effect of the achievement variable but also a significant gender $\times$ achievement interaction effect occurred. Within the low achieving subgroup the female learners displayed substantially lower self-concept scores than their male counterparts - at least concerning the latest mark criterion. Hence, they more strongly suffered from internal distress.

Discussion. Especially, in the L2 English language subject a gender $\times$ achievement interaction effect could significantly explain differences in the learners' self-concept. Consequently, these differences cannot merely ascribed to a gendered view of language subjects - which commonly favors the female learners. Gender stereotyping effects will operate in a more complex manner. In particular, they appear to affect the students' self-concept not primarily as a matter of subject rather as a matter of cognitive-motivational processing in the case of individually cumulated failure experiences - thus evidently unfavoring the female learners. However, the findings considerably differed across both the L1 and the L2 language subject and, thus, still need further clarification.

Keywords: verbal self-concepts, language proficiency, foreign language learning, gender differences, internal distress. 


\section{Diferencias de género y de rendimiento en los auto-conceptos de los alumnos de Secundaria: más allá de la comparación bivariable}

\section{Resumen}

Introducción. En el contexto de los resultados de investigación contradictorias en el campo del estudio dirigido a desentrañar las complejidades estructurales de las diferencias de género en el autoconcepto, en los las lenguas secundarias, se estudia el análisis de la interacción género $\times$ rendimiento, en los efectos de la perimera y segunda lengua, la L1 y la L2, en el idioma alemán e inglés. Se asume de partida, que la activación en espinal a malestar interno, como una variable, de perspectiva significativa del autoconcepto, tiene efectos en las calificaciones de los estudiantes de sexo femenino, en particular.

Método . Los datos fueron recogidos en una muestra de 256 estudiantes de noveno grado del alemán gramo del centro de una ciudad alemana. Para L1 y L2 la medición del autoconcepto se les administró dos escalas de materias específicas de autoinforme. Para medir su rendimiento en cada profesor de la asignatura de lengua aportó las calificaciones en competencias.

Resultados. Con respecto a la L1 de idioma alemán, apareció sólo un efecto principal significativo en el logro de la variable de ambiente. Ni un efecto de género ni un logro $\times$ inter-género de acción se pudo demostrar. Por lo tanto, las diferencias interindividually existentes en autoconcepto, a favor de las estudiantes femeninas parecen reflejar en gran parte su mejor rendimiento lenguaje nativo. Con respecto a la lengua L2 o, asimismo, apareció un significativo efecto principal de la variable logro y también un efecto de interacción significativo género $\times$ rendimiento. En el subgrupo de baja el logro de la de los estudiantes masculinos, apareción un significativo menor auto-concepto con resultados peores que sus homólogos masculinos, al menos para las últimas puntuaciones.

Discusión. Especialmente, para el idioma Inglés L2, la interacción género $\times$ logro perfecta podría explicar diferencias significativas en el autoconcepto de los alumnos. En consecuencia, las diferencias no están asociadas a una visión de género languaje- que comúnmente favorece a los estudiantes varones. El efecto de los estereotipos de género parece tener una forma más compleja de mediación en los resultados. En particular, parecen afectar a los estudiantes en el autoconcepto, en un nivel cognitivo motivacional, como con secuencia de los fallos en las experiencias. Como otras veces, el hallazgo de las diferencias entre lenguas, tanto la L1 y la L2, deberá seguir aclarándose.

Palabras clave: aptitud verbal, autoconcepto verbal, lenguaje, aprendizaje de lenguas extranjeras, diferencias de género, angustia interna. 


\section{Introduction}

Current conceptual perspectives and empirical findings on academic achievement broadly agree to regard the students' cognitive-motivational orientations as an important developmental factor (Artelt, Baumert, Julius-McElvany \& Peschar, 2003; DiPerna, Volpe \& Elliott, 2001; Hattie, 2009; Lee \& Shute, 2010). These cognitive-motivational orientations manifest as the students' self-related beliefs which can refer to their subjective appraisals, explanations, and values of academic activities and outcomes. In particular, they substantially concern the individually existing perceptions of competence and control with respect to a certain educational setting. Developmentally, they can be understood both as consequences of previous academic experiences and as antecedents of future academic outcomes (Pintrich, 2003). Theoretically, they can be defined as expectancy-value constructs which predict to a large extent how an academic situation is being either approached or possibly avoided. Therefore, they considerably contribute to regulate the students' individual engagement and learning behavior in the long term (Wigfield, Eccles, Schiefele, Roeser \& Davis-Kean, 2006; Zimmerman \& Cleary, 2009).

Among these self-beliefs, the students' academic self-concept has been evidenced as a cognitive-motivational key variable. In terms of self-perceptions and self-evaluations of one's own capabilities, it is assumed to be multifaceted in nature and to be comprised of distinct subconcepts or components - which in particular refer to the students' competence beliefs in a certain academic domain, subject, or with respect to a certain type of academic task. Accordingly, in numerous educational and psychological studies these self-concept facets could be empirically separated (Byrne, 1996; Marsh \& O’Mara, 2008). Across most diverse research designs and student samples, domain- or subject-specific self-concept variables have been consistently demonstrated to correlate with corresponding performance indicators in a differential manner and, thus, can explain a higher degree of convergent achievement variances than general measures of academic self-concept or global self-esteem (Bong, Cho, Ahn \& Kim, 2012; Möller, Pohlmann, Köller \& Marsh, 2009; Valentine, DuBois \& Cooper, 2004). The formation and maintenance of academic self-concepts can be essentially explained as the result of comparative information processing, which evidently reflects various frames of reference. In particular, the students' domain- or subject-specific self-concepts appear to develop by social (external) comparisons of their own academic outcomes with the outcomes of class- 
mates and the average outcome level of their class or school environment (Seaton, Marsh \& Craven, 2009), by dimensional (internal) comparisons of their academic outcomes across different domains or subjects, and by criterion-related comparisons of their academic outcomes with decisive standards in a certain domain or subject (Dijkstra, Kuyper, van der Werf, Buunk \& van der Zee, 2008; Skaalvik \& Skaalvik, 2002).

\section{Gender Differences in Domain-Specific Self-Concepts}

However, the formation and maintenance of students' academic self-concepts does not merely depend on their comparative processing of achievement information but also might be substantially affected by their gender. Though females and males display equal outcomes in a certain domain or subject they may significantly differ in their related self-beliefs (Skaalvik \& Skaalvik, 2004). These differences must be considered, for the most part, as the result of gender stereotyping practices which primarily take place in the family and school setting (Eccles, Jacobs \& Harold, 1990; Marsh, 1989; Tiedemann, 2000).

Thus, as the gender gap in mathematics achievement has apparently decreased throughout the past decades (Else-Quest, Hyde \& Linn, 2010; Mullis, Martin, Goldberg \& Stemler, 2000), self-concept differences favoring the males are to be found further on. Even when existing differences in mathematics test scores or grades were statistically controlled for, male students consistently reported higher self-concept scores than female students. Consequently, gender differences in the mathematics self-concept can hardly be traced to related achievement differences but will rather be induced by domain-specific stereotypes (Brunner, Keller, Hornung, Reichert \& Martin, 2009; Frenzel, Pekrun \& Goetz, 2007; Marsh \& Yeung, 1998; Rustemeyer \& Fischer, 2005; Sáinz \& Eccles, 2012; Schilling, Sparfeldt \& Rost, 2006; Steinmayr \& Spinath, 2008). A number of studies could demonstrate that this gender-biased pattern in students' self-concepts already appeared to emerge in the early elementary grades and to persist in the course of elementary school (Dickhäuser \& Meyer, 2006; Herbert \& Stipek, 2005; Faber, Tiedemann \& Billmann-Mahecha, 2011; Köller, Zeinz \& Trautwein, 2008; Lindberg, Linkersdörder, Ehm, Hasselhorn \& Lonnemann, 2013; Meelissen \& Luyten, 2008; Tiedemann \& Faber, 1995).

Compared with this, similar gender differences in the verbal domain are less clear. With respect to the native language (L1) subject, empirical research findings mostly could de- 
monstrate that female students outperformed their male classmates in reading and spelling across various age levels and educational tracks, though these differences strongly varied in magnitude and often turned out rather small (Chiu \& McBride-Chang, 2006; De Fraine, Van Damme \& Onghena, 2007; Gambell \& Hunter, 1999; Hay, Ashman \& van Kraayenoord, 1998; Rouxel, 2000; Steinmayr \& Spinath, 2008; Winkelmann \& Groeneveld, 2010). However, this advantage does not appear to be consistently associated with higher self-concepts in female learners. Most studies reported higher verbal self-concepts for female students (Berg \& Klinger, 2009; Hay, Ashton \& van Kraayenoord, 1998; Hergovich, Sirsch \& Felinger, 2004; Jacobs, Lanza, Osgood \& Eccles, 2002; Rinn, McQueen, Clark \& Rumsey, 2008; Wilgenbusch \& Merrel, 1999). When statistically controlled for verbal competencies, the selfconcept differences between females and males diminished (Faber \& Billmann-Mahecha, 2012; Schilling, Sparfeldt \& Rost, 2006) - indicating the females' self-beliefs to be congruently or even realistically in line with their performance level. On the other hand, some studies could not substantiate any gender differences in verbal self-concepts (De Fraine, Van Damme \& Onghena, 2007; Faber, 2003; Skaalvik \& Skaalvik, 2004). Moreover, when statistically controlled for verbal competencies, the self-concept differences between females and males in some cases remained (Ehm, Duzy \& Hasselhorn, 2011) or apparently increased in favor of the male students despite their lower outcomes (Frühauf, 2008; Treutlein \& Schöler, 2009).

Furthermore, with respect to the foreign language (L2) subject there are similar research findings. Here again, across various grade levels and educational tracks the female students consistently displayed better outcomes in learning English as a foreign language than male students (Hartig \& Jude, 2008; Lehmann, Gänsfuß \& Husfeldt, 2011; Nikolova, 2011; Nikolova \& Ivanov, 2010; Schilling, Sparfeldt \& Rost, 2006; Winkelmann \& Groeneveld, 2010; Zaunbauer, Retelsdorf \& Möller, 2009). However, whilst some studies reported significant self-concept differences favoring the female language learners (Dörnyei \& Clément, 2001; Du, 2012; Heinzmann, 2009; Henry, 2009; Schilling, Sparfeldt \& Rost, 2006), other studies failed to demonstrate any gender differences in the L2 self-concept (Daniels, 2008; Helmke, Schrader, Wagner, Nold \& Schröder, 2008; Holder, 2005; Krätschmar, 2010; Kurman, 2004; MacIntyre, Baker, Clément \& Donovan, 2002; Skaalvik \& Skaalvik, 2004; Zaunbauer, Retelsdorf \& Möller, 2009). 


\section{Refining Research Perspectives on Gender Differences}

Taken altogether, empirical research findings on gender differences in verbal selfconcepts appear to be mixed and, thus, might be partially originate in methodological diversities across studies - e.g. in various grade levels, educational settings, and, not least, in validity problems of certain self-concept measures. For instance, some particular analyses concerning the students' self-beliefs in the L2 subject had used aggregated composite scores of self-efficacy and language anxiety (Dörnyei \& Clément, 2001) or only affective value items to assess the self-concept variable (Henry, 2009). Consequently, a methodologically sound analysis of gender differences in verbal self-concepts should, most of all, use theoretically appropriate and empirically well proven instruments which are able to assess the students' subject-specific appraisals and expectancies in a psychologically representative manner.

With this principal reservation, those studies which could not substantiate any significant gender differences in the students' verbal self-concepts might have indicated, however, the female students to potentially underestimate and the male students to potentially overestimate their language proficiency (Bornholt, Goodnow \& Cooney, 1994; Cole, Martin, Peeke, Seroczynski \& Fier, 1999; Watt, 2004). Accordingly, as several empirical analyses could correspondingly demonstrate, female students commonly were more likely to perceive themselves defensively and thus were more likely to discount their competencies (Stetsenko, Little, Gordeeva, Grasshof \& Oettingen, 2000; Stipek \& Gralinski, 1991), whereas male students tended to maintain more ego-enhancing self-evaluations (Hattie \& Marsh, 1996; Skaalvik \& Skaalvik, 2004). In particular, female learners were more prone to internalizing and ruminative reactions in the face of academic failure (Broderick, 1998; Frenzel, Pekrun \& Goetz, 2007; Kiuru, Leskinen, Nurmi \& Salmelo-Aro, 2011). They adjusted their self-perceptions downward after experiencing failure (Crosnoe, Riegle-Crumb \& Muller, 2007), and they accepted greater responsibility for bad academic outcomes (Bornholt \& Möller, 2003; Georgiou, Stavrinides \& Kalavana, 2007; Rijavec \& Brdar, 1997; Rusillo \& Arias, 2004; Tiedemann \& Faber, 1995). In general, female students reported internal distress primarily after academic failure to a significantly greater extent than male students (Pomerantz, Altermatt \& Saxon, 2002; Ziegler \& Stöger, 2002). Therefore, those research findings which could not demonstrate any gender differences in verbal self-concepts might be explained by a typically operating gender bias in the cognitive-motivational processing of individually experienced failure - that is, in the case of a relatively or contextually lowered achievement level. Accordingly, at 
the same (bad) achievement level female learners would display comparatively weaker competence beliefs than their male counterparts. Thus, the possible impact of gender bias in verbal self-concepts should be essentially moderated by the students' individual achievement or proficiency level, or even specified with respect to academic failure situations. In terms of theoretical frameworking, gender differences in verbal self-concepts will not sufficiently be predicted by means of a gendered view hypothesis favoring female learners in general (Räty, Kasanen \& Kärkkäinen, 2006).

The need for a conceptually refined analysis of gender differences in verbal self-concepts appears to be additionally supported by several empirical findings dealing with differential patterns in the relation between achievement and self-concept variables. In particular, some of these findings could demonstrate the self-concept differences between low achieving and average or high achieving high school students being significantly strongest in magnitude (Haynes, Hamilton-Lee \& Comer, 1998; Rao, Moely \& Sachs, 2000). In contrast, another finding from secondary grades could show the self-concept differences between high and average achieving students being significantly greater than between average and low achieving students (Möller \& Pohlmann, 2010). Furthermore, albeit using a general measure of academic self-concept, a particular study reported a stronger magnitude of gender differences in the subsample of low achieving seventh-graders (Lehmann, Gänsfuß \& Peek, 2011). Although these contradictory research outcomes do not allow for drawing a clear conclusion about the nature of achievement-related differences in verbal self-concepts, they nevertheless recommend an intensified use of multivariate analyses which should simultaneously clarify the relations among relevant self-belief and achievement constructs with the gender variable and, therefore, might warrant a more appropriate research perspective on the gender bias issue. Unfortunately, many previous studies in the field had used bivariate methods to compare female and male self-concepts in the verbal domain. Therefore, their results might have left undiscovered actually existing differences with respect to certain achievement levels.

Hence, a closer look on gender differences beyond bivariate comparison should contribute to unravel the complexity of relevant gender differences. According to the perspective of the internal distress approach a multivariate analysis of gender differences in verbal selfconcepts which also includes various achievement levels should be able to identify relevant interaction effects. In particular, substantial self-concept differences between female and male students at a lowered achievement level should be assumed. 


\section{Objectives of the Present Study}

In order to comprehensively test the assumption that interindividually existing differences in the students' verbal self-concepts might be sufficiently substantiated by an achievement level $\times$ gender interaction the bivariate comparison results of a previously investigated data set from a sample of secondary ninth-graders (Faber, 2012a) should be further analyzed by multivariate procedures. With respect to the German (L1) language subject, these preliminary results could demonstrate highly significant advantages in teacher competency ratings (d $=-.70)$ and latest marks $(d=0.75)$ as well as in the L1 self-concept $(d=-0.57)$ for the female students. With respect to the English (L2) language subject, neither in teacher competency ratings $(d=0.11)$ or latest marks $(d=0.11)$ nor in the L2 self-concept $(d=0.03)$ any significant gender differences could be found (Figure 1).

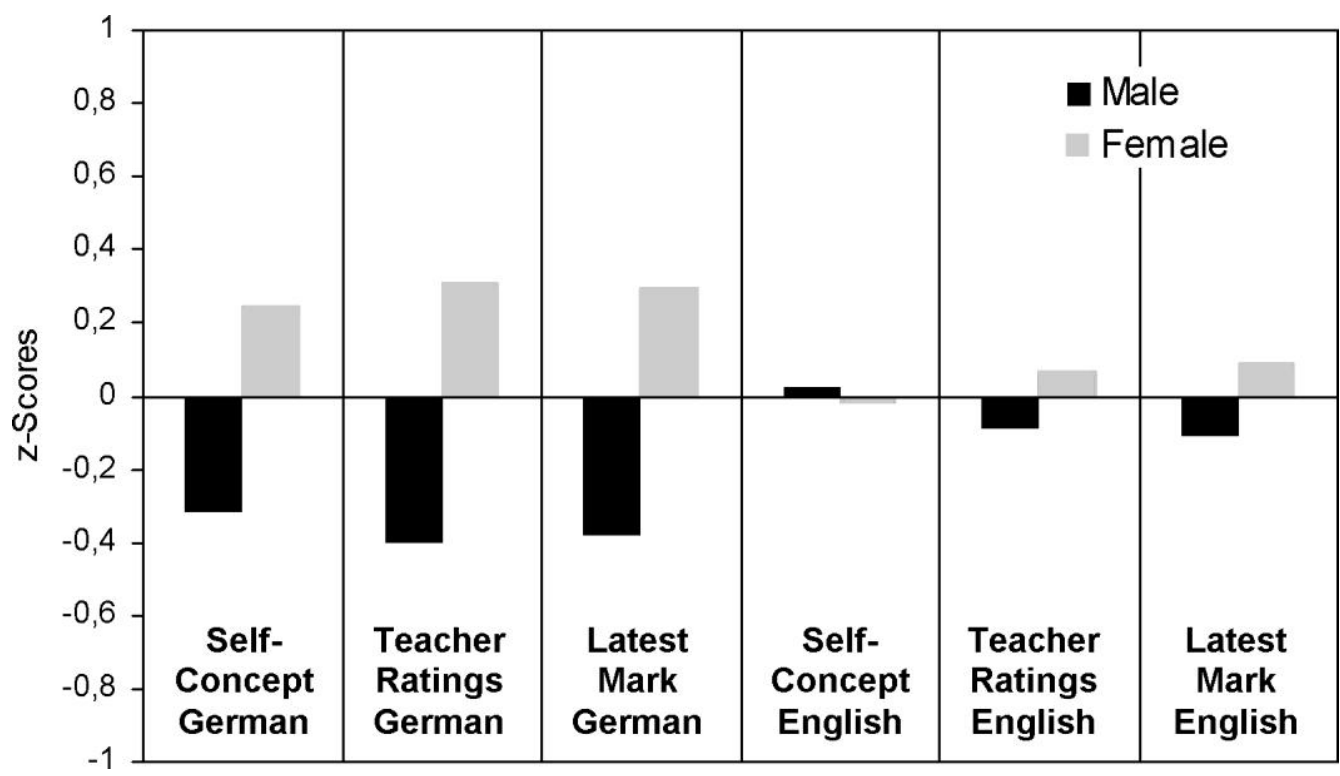

Figure 1. Gender differences in L1 German and L2 English achievement and self-concept measures: Results of bivariate comparisons (Faber, 2012a)

Unexpectedly, against the typically reported research findings (Hartig \& Jude, 2008; Skaalvik \& Skaalvik, 2004) only minor achievement differences in the L2 subject did occur. Moreover, they evidently did not have any impact on the students' self-concept. At first glance, these results indicated a gender effect being strong in the L1 and weak in the L2 self-concept. However, these results cannot clarify to what extent the higher L1 self-concept scores of 
female learners would mirror their achievement advantage or also imply subject-specific stereotyping effects (Schilling, Sparfeldt \& Rost, 2006). Furthermore, in both the L1 and L2 self-concept they might still have masked actually existing gender differences within the low achieving subgroup, in particular potentially emerged underestimations and ruminative appraisals to the disadvantage of the female students. Against this background, the present study aimed at examining the following research hypotheses:

1. In the German (L1) subject self-concept differences should be best explained by a significant main effect of related achievement variables.

2. Mean differences in the L1 self-concept should be significantly strongest between the low and the average achieving subgroup, respectively.

3. Under statistical control of the achievement variables, differences in the L1 self-concept should be significantly explained by an achievement $\times$ gender interaction effect.

4. Rather at the low (than at the average or high) achievement level female learners should report significantly lower scores in the L1 self-concept than male learners.

5. In the English (L2) subject self-concept differences should be best explained by a significant main effect of related achievement variables.

6. Mean differences in the L2 self-concept should be significantly strongest between the low and the average achieving subgroup, respectively.

7. Under statistical control of the achievement variables differences, in the L2 self-concept should be significantly explained by an achievement $\times$ gender interaction effect.

8. Rather at the low (than at the average or high) achievement level female learners should report significantly lower scores in the L2 self-concept than male learners.

\section{Method}

\section{Participants}

The study was conducted with a sample of $N=256$ students (144 females, 112 males) from 20 ninth-grade grammar school classes of a large urban catchment. In the German tripartite system of strongly selective educational tracks this school type ("Gymnasium") is the highest track. The students' average age was 15.0 years $(S D=0.5)$. Their participation was on a voluntary basis and only with explicit parental consent. The predominant majority of participating students $(N=222)$ declared themselves to be born in Germany. With respect to the English and German achievement measures, the students who were not born in Germany did not significantly differ from their classmates ( $\mathrm{t}$-tests for independent samples: $p>.05$ ). 


\section{Procedure}

The self-belief and achievement data were gathered in the course of two class periods by two (advanced collegiate) test supervisors, respectively, who had been instructed in detail prior to the beginning of the test. This took place class for class and in the absence of the teaching staff. The teaching staff in charge collected additional competence data with corresponding questionnaires for the German and English subject.

\section{Variables and Measurements}

The academic self-concepts in the L1 German and the L2 English were assessed using 14 six-point Likert items for each language. They addressed the extent of subjective competence expectations with regard to meeting academic demands. In the majority, these questionnaire items originate from pertinent time-tested instruments, and they were presented in the economical grid style format (Baumert, Gruehn, Heyn, Köller \& Schnabel, 1997; Faber, 2012c; Rost, Sparfeldt \& Schilling, 2007). The wording of the items for both language subjects was strictly parallel. No explicit social or dimensional comparisons were verbalized. Sample item: "I try hard in English, but I do not perform very well." It was possible to form two scales for measuring subject-specific self-concepts. The results of a confirmatory factor analysis showed an appropriate fit of the measurement model (Faber, 2012a). The latent selfconcept variables were correlated to a moderate extent $(\mathrm{r}=.36, \mathrm{p} \leq .001)$. For both scales the internal reliabilities turned out to be highly sufficient (Cronbach's alpha $\alpha=.92$ for German and $\alpha=.94$ for English). High scale scores indicated positive perceptions and evaluations of the students' own subject-specific competence (Faber, 2009).

Different indicators were used for assessing academic achievement in each language subject. Concerning relevant competence aspects, the respective teaching persons were asked to complete a questionnaire consisting of seven rating items. In particular, they concerned the students' proficiency level in English and German - e.g. their competencies in reading comprehension, spelling, grammar, oral language use, composition (Faber, 2009). In terms of principal components analysis, these subject-specific teacher ratings could clearly be separated. Both factors could explain overall nearly $80 \%$ of the entire trait variance. For both teacher rating scales the internal reliabilities turned out to be highly sufficient (Cronbach's alpha $\alpha=$ .95 for German and $\alpha=.95$ for English). As additional performance information, the students' latest school marks in both subjects were assessed. In agreement with studies of this kind that 
cannot identify seriously biased limitations in the accuracy of judgment in comparable age groups, these grades were self-reported by the students (Kuncel, Credé \& Thomas, 2005; Möller, Streblow, Pohlmann \& Köller, 2006). The teacher ratings and grades proved to correlate in English to $\mathrm{r}=.72$ and in German to $\mathrm{r}=.77(\mathrm{p} \leq .001)$. Gender was included as a dummy variable (coding: male $=1$, female $=2$ ) in the analyses.

\section{Data Analyses}

Whereas the self-reported school marks in both language subjects were complete, among the self-concept items and teacher ratings there were a few missing data (amounting at most to $4.7 \%$ ). As these missings did not produce any systematic pattern they were treated as "missing at random" (MAR) and, therefore, were estimated by means of the two-step iterative EM algorithm (Enders, 2010). In order to rule out even minor classroom effects, for all variables classwise z-standardized scores were calculated (Faber, 2012a). For determining the relative contribution of achievement level and gender to explain interindividually existing differences in both the L1 and L2 self-concept, first of all, separate two-way $3 \times 2$ analyses of variance (ANOVA) were run with the teacher competence ratings or the students' latest marks, respectively, and gender as independent factor variables. Both achievement variables in each language subject were factorized using their empirical tertiles, thus, leading to the identification of a low, average, and high achieving subgroup in each case. Moreover, for examining mean self-concept differences among these achievement levels post hoc multiple comparisons were performed - using the Scheffé test which appears to be the most flexible and robust, though rather conservative procedure (Kirk, 1982). Self-concept differences between females and males within each achievement level were analyzed with two sample Welch t-tests (Ruxton, 2006). In order to adequately control the familywise Type I error rate, the alpha level for deciding statistical significance was adjusted with Holm's sequential procedure (1979). Additionally, for all pairwise comparisons Hedges' g (1982) was calculated as effect size which pools the n-weighted standard deviations of each subgroup under consideration (Durlak, 2009).

\section{Results}

The results of two-way univariate variance analyses drew a quite different pattern across both language subjects. In the L1 German, the students' self-concept could be best explained by a statistically significant main effect of the teacher competence ratings and the 
latest marks, respectively (Table 1). Concerning the latest mark variable, the low achieving female learners reported a slightly lessened self-concept, though (Figure 2). However, this difference was marginal in nature. Overall, neither a significant main effect of the students' gender nor a significant interaction effect between gender and achievement occurred. Interindividually existing self-concept differences in favor of the female learners, therefore, appeared to largely reflect their better achievement in the native language subject.

\section{Table 1. Effects of achievement and gender on L1 German and L2 English self-concepts: Results of two-way analyses of variance}

Dependent Variable: Self-Concept L1 German

\begin{tabular}{lcrcc}
\hline Factor Variables & $\mathrm{df}$ & $\mathrm{F}$ & $\mathrm{p}$ & $\eta^{2}$ \\
\hline Teacher Ratings & 2,255 & 65.419 & .000 & .344 \\
Gender & 1,255 & 3.260 & .072 & .013 \\
Teacher Ratings $\times$ Gender & 2,255 & 0.458 & .633 & .004 \\
Latest Mark & 2,255 & 85.271 & .000 & .406 \\
Gender & 1,255 & 0.549 & .459 & .002 \\
Latest Mark $\times$ Gender & 2,255 & 1.857 & .158 & .015 \\
\hline Dependent Variable: Self-Concept L2 English & & & \\
\hline Factor Variables & $\mathrm{df}$ & $\mathrm{F}$ & $\mathrm{p}$ & $\eta^{2}$ \\
\hline Teacher Ratings & 2,255 & 77.100 & .000 & .381 \\
Gender & 1,255 & 2.795 & .096 & .011 \\
Teacher Ratings $\times$ Gender & 2,255 & 3.422 & .034 & .027 \\
Latest Mark & 2,255 & 120.667 & .000 & .491 \\
Gender & 1,255 & 4.378 & .037 & .017 \\
Latest Mark $\times$ Gender & 2,255 & 3.184 & .043 & .025 \\
\hline
\end{tabular}

Note. $\mathrm{df}=$ degrees of freedom, $\mathrm{F}=\mathrm{F}$-value, $\mathrm{p}=$ probability, $\eta^{2}=$ effect size

In the L2 English, a similarly strong main effect of the teacher competence ratings and the latest marks, respectively, was found. For the latest marks but not for the teacher ratings also a significant main effect of the gender variable occurred. Furthermore, with respect to both achievement variables a significant interaction effect could be demonstrated - which still accounted for 27 and 25 per cent of the L2 self-concept variance (Table 1). It was the female learners who reported apparently lower self-concept scores at the low and, to a lesser extent, at the average achievement level than their male counterparts. At the high achievement level they displayed, if at all, somewhat higher self-concept scores. Hence, at the lower achieve- 
ment level the female learners seemingly experienced a stronger degree of failure awareness and, thus, a greater amount of internal distress (Figure 2).
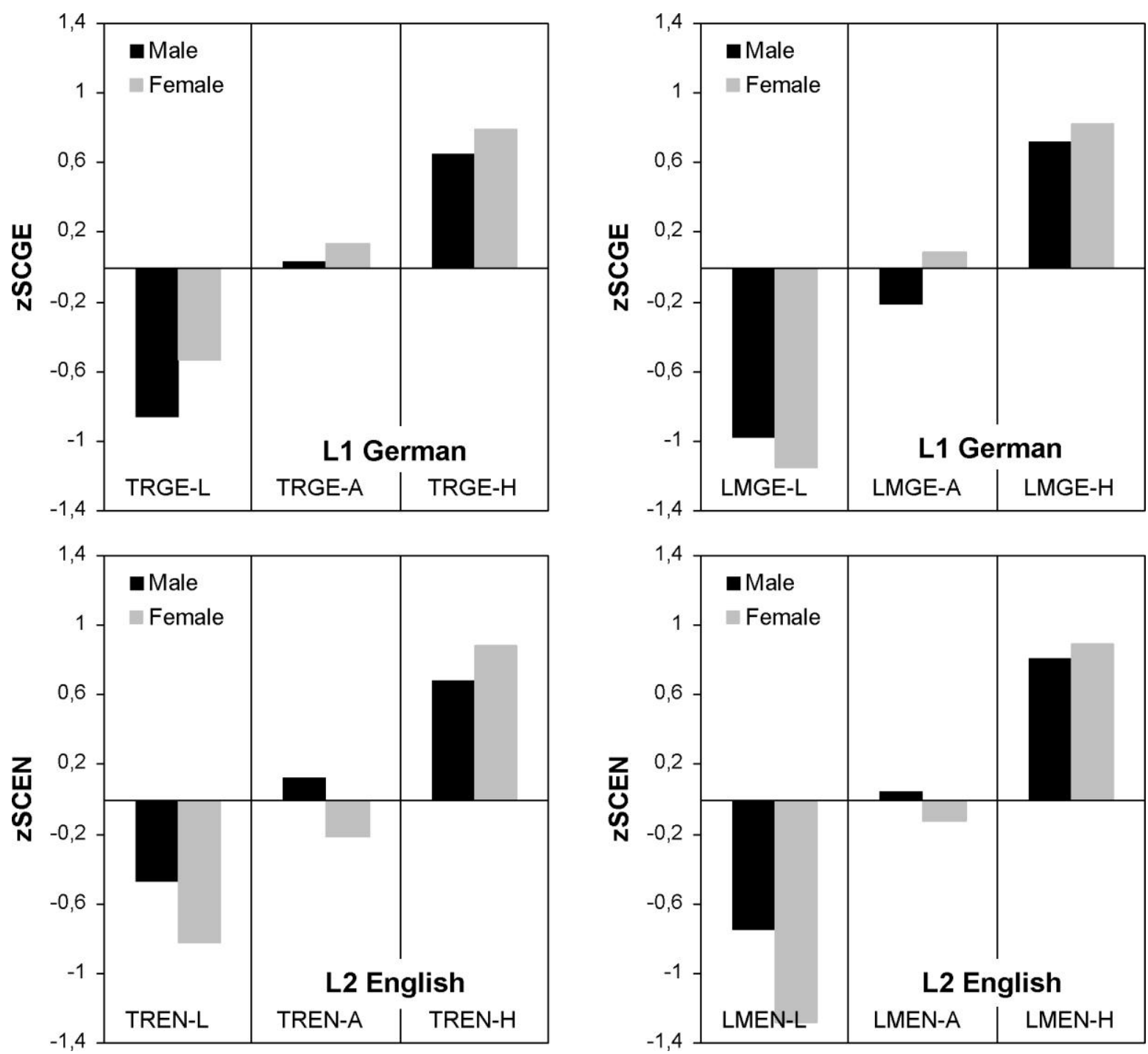

Figure 2. Gender- and achievement-dependent differences in L1 German and L2 English selfconcept scores $(T R=$ teacher competence ratings, $L M=$ latest mark, $L=$ low, $\mathrm{A}=$ average, $\mathrm{H}=$ high)

Moreover, additionally conducted post hoc comparisons revealed statistically significant self-concept differences among all achievement groups (Table 2). In the L1 German as well as in the L2 English language subject the students' verbal self-concepts throughout differed between all levels of teacher ratings and latest marks - each difference reaching a considerably strong effect size. In particular, there was no increase in mean self-concept differences between the low and average achievement group. Thus, an individually emerging de- 
cline in the female learners' L2 self-perceptions could not have been primarily engendered by a nonlinear association between the achievement and the self-concept variable.

Table 2. Mean self-concept differences among L1 German and L2 English achievement levels: Results of post hoc comparisons using Scheffé's test procedure

\begin{tabular}{|c|c|c|c|c|c|}
\hline \multirow[t]{2}{*}{ L1 German } & \multicolumn{2}{|c|}{ Teacher Ratings } & & \multicolumn{2}{|c|}{ Latest Mark } \\
\hline & Level 2 & Level 3 & & Level 2 & Level 3 \\
\hline Level 1 & -0.823 & -1.488 & Level 1 & -0.982 & -1.830 \\
\hline $\mathrm{g}$ & & L13 1.90 & $\mathrm{~g}$ & & L13 2.52 \\
\hline Level 2 & & -0.664 & Level 2 & & -0.848 \\
\hline $\mathrm{g}$ & L12 0.98 & L23 0.92 & $\mathrm{~g}$ & L12 1.22 & L23 1.19 \\
\hline \multirow[t]{2}{*}{ L2 English } & \multicolumn{2}{|c|}{ Teacher Ratings } & & \multicolumn{2}{|c|}{ Latest Mark } \\
\hline & Level 2 & Level 3 & & Level 2 & Level 3 \\
\hline Level 1 & -0.599 & -1.469 & Level 1 & -0.985 & -1.906 \\
\hline $\mathrm{g}$ & & L13 1.89 & $\mathrm{~g}$ & & L13 2.88 \\
\hline Level 2 & & -0.870 & Level 2 & & -0.921 \\
\hline $\mathrm{g}$ & L12 0.70 & L23 1.24 & $\mathrm{~g}$ & L12 1.34 & L23 1.36 \\
\hline
\end{tabular}

Note. Level 1 = low, Level 2 = average, Level 3 = high achievement scores $\mathrm{g}=$ Hedges' effect size (unsigned absolute value)

Significance: $\mathrm{p} \leq .001$ for all mean differences

For further clarification of the gender $\times$ achievement interaction effect, which contributed to partially explain the L2 self-concept variance, pairwise comparisons between equally performing female and male learners were calculated. At first sight, the results of Welch ttests could substantiate remarkably lowered self-concept scores for the female learners in the lower group of teacher competence ratings and latest marks (Table 3). However, only the difference in the latest mark variable did not exceed the adjusted alpha level and turned out being statistically significant. This difference also reached a large effect size which accounted for more than a half standard deviation. Within the lower level of L2 marks, the female learners' self-concept appeared to be more strongly depressed than the self-concept of their male counterparts.

\section{Discussion}

The present study aimed at unraveling the structural complexities of gender differences in secondary students' verbal self-concepts and, thus, analyzing possible gender $\times$ achievement interaction effects in the L1 German and L2 English language subject. According to 
an internal distress perspective (Kiuru, Leskinen, Nurmi \& Salmelo-Aro, 2011; Pomerantz, Altermatt \& Saxon, 2002), significantly depressed self-concept scores for the female learners, in particular, at the low achievement level were assumed.

Table 3. Mean z-scores in males' and females' L2 English self-concept: Results of multiple comparisons within achievement level

\begin{tabular}{lcccrrr}
\hline & \multicolumn{3}{c}{ Teacher Competence Ratings } & \multicolumn{3}{c}{ Latest Mark } \\
& Level 1 & Level 2 & Level 3 & Level 1 & Level 2 & Level 3 \\
\hline Male & -0.473 & 0.128 & 0.686 & -0.756 & 0.013 & 0.809 \\
Female & -0.826 & -0.215 & 0.886 & -1.276 & -0.126 & 0.893 \\
$\mathrm{t}$ & 2.046 & 1.796 & -1.472 & 2.708 & 0.961 & -0.680 \\
$\mathrm{p}$ & .022 & .039 & .073 & .005 & .169 & .249 \\
$\alpha$ & .010 & .013 & .017 & .008 & .025 & .050 \\
$\mathrm{~g}$ & 0.40 & 0.43 & 0.33 & 0.67 & 0.15 & 0.16 \\
\hline Note. $\mathrm{t}=\mathrm{t}$-value, $\mathrm{p}=$ one-tailed probability, $\alpha$ ' $=$ adjusted alpha level \\
$\mathrm{g}=$ Hedges' effect size (unsigned absolute value)
\end{tabular}

In the L1 German language subject the results of multivariate analyses could only demonstrate a significant main effect of the achievement variables. Hence, apparently existing gender differences in the L1 self-concept were in line with the female learners' better achievement. Therefore, they could not be explained by an internal distress bias. Compared with this, in the L2 English language subject the results of multivariate analyses could substantiate a significant gender $\times$ achievement interaction effect. Contradictory to related research findings reported elsewhere (Hay, Hamilton-Lee \& Comer, 1998; Rao, Moely \& Sachs, 2000) mean self-concept differences were not significantly strongest between the low and average achieving subgroup. However, within the low achieving subgroup the female learners displayed significantly lower self-concept scores than their male counterparts - at least with respect to the latest mark variable. With respect to the teacher competence ratings, this effect also appeared but did not reach statistical significance. Methodologically, this particular finding undoubtedly results from the conservative procedure of alpha adjustment. Conceptually, it might indicate the latest marks to provide more salient information to the students' self-perceptions than the teacher ratings - which, in turn, might not have been sufficiently communicated in the EFL classroom. Nevertheless, in the L2 English language subject the internal distress hypothesis could be principally supported. Interindividually existing selfconcept differences appeared to be gender biased at the lower achievement level and, thus, essentially were associated with the female learners' depressed self-beliefs. Obviously, they 
more strongly suffered from internalizing, even ruminative responses to failure experiences than equally achieving male learners. In the long term, they might be at risk for motivationally less adaptive self-regulation strategies which should additionally hinder their academic development.

At least with respect to the L2 English language subject, the findings of the present study lent partial support to an internal distress perspective on gender differences in the students' related self-concept. Hence, interindividually existing differences in L2 learners' competence beliefs cannot merely be ascribed to a gendered view of language subjects - which commonly favors the female learners (Räty, Kasanen \& Kärkkäinen, 2006; Williams, Burden \& Lanvers, 2002; Steffens \& Jelenec, 2011). Gender stereotyping effects will operate in a more complex manner. In particular, they appear to affect the students' self-concept not primarily as a matter of subject but rather as a matter of cognitive-motivational processing in the case of individually cumulated failure experiences - thus evidently unfavoring the female learners. Consequently, the issue of gender bias in the L2 self-concept must be more generally traced to a constraint in female learners' motivational coping resources. Additional support for this perspective comes from similar findings concerning task-specific self-beliefs in the L2 English language subject. It was also the female learners who reported a considerably higher amount of worry and emotionality cognitions than the equally achieving male learners (Faber, 2012 b). Future research should, therefore, scrutinize the developmental influences which contribute to the females' stronger vulnerability to internal distress (Papadakis, Prince, Jones \& Strauman, 2006) - e.g. analyzing the role of parents' and teachers' impact on motivational orientations and coping strategies (Kurtz-Costes, Rowley, Harris-Britt \& Woods, 2008; Meece, Glienke \& Askew, 2009).

Taken altogether, the findings considerably differed across both the L1 and the L2 language subject. Against the most empirical evidence from related research (Hartig \& Jude, 2008; Lehmann, Gänsfuß \& Husfeldt, 2011; Schilling, Sparfeldt \& Rost, 2006; Winkelmann \& Groeneveld, 2010) in the sample under consideration no gender differences in the L2 English language achievement could be found. Moreover, as the developmental associations between the students' L1 skills and L2 proficiency are well proven in general (Sparks, 2010; Van Gelderen, Schoonen, Stoel, de Glopper \& Hulstijn, 2007), the female learners' advantage in the native language did not transfer to their foreign language outcomes. Even though a similar finding could be demonstrated elsewhere in a small sample of secondary foreign lan- 
guage learners (Dewaele, 2007), these twofoldly unexpected results deserve further attention. They emphasize, in any case, the need for relevant replication studies which also should include other educational tracks, grade levels, and alternate achievement measures. Likewise, these studies should seek to clarify why the internal distress phenomenon in female learners did not analogously emerge at the L1 low achievement level.

Not least, the findings of the present study convincingly underline the need for multivariate analyses of gender differences in the field of academic self-concept research. Only bivariate comparison methods must fail to uncover the complex relations among the students' gender, self-beliefs and achievement. Albeit being preliminary in nature, the findings might offer useful implications for instructional settings, yet. From the perspective of the internal distress issue they point out the multiple determination of emergent gender differences in the verbal domain and, thus, recommend educational assessment procedures which should not simply infer the students' motivational orientations from their currently existing outcomes. In particular in the case of lasting failure experiences, rather an individualizing and disentangling exploration of their academic self-beliefs is needed (Martin, 2010).

\section{References}

Artelt, C., Baumert, J., Julius-McElvany, N., \& Peschar, J. (2003). Learners for life. Student approaches to learning. Results from PISA 2000. Paris: Organization for Economic Co-Operation and Development (OECD).

Baumert, J., Gruehn, S., Heyn, S., Köller, O., \& Schnabel, K. (1997). Bildungsverläufe und psychosoziale Entwicklung im Jugendalter (BIJU). Band 1: Welle 1-4 [Academic and psychosocial development during adolescence]. Berlin: Max-Planck-Institut für Bildungsforschung.

Berg, D.H., \& Klinger, D.A. (2009). Gender differences in the relationship between academic self-concept and self-reported depressed mood in school children. Sex Roles, 61, 501509. DOI: 10.1007/s11199-009-9652-2.

Bong, M., Cho, C., Ahn, H.S., \& Kim, H.J. (2012). Comparison of self-beliefs for predicting student motivation and achievement. Journal of Educational Research, 105, 336-352. DOI: 10.1080/00220671.2011.627401.

Bornholt, L.J., Goodnow, J.J., \& Cooney, G.H. (1994). Influences of gender stereotypes on adolescents' perceptions of their own achievement. American Educational Research 
Journal, 31, 675-692. DOI: 10.3102/00028312031003675.

Bornholt, L., \& Möller, J. (2003). Attributions about achievement and intentions about further study in social context. Social Psychology of Education, 6, 217-231. DOI: 10.1023/A: 1024715609124.

Broderick, P.C. (1998). Early adolescent gender differences in the use of ruminative and distracting coping strategies. Journal of Early Adolescence, 18, 173-191. DOI: 10.1177/0 272431698018002003.

Brunner, M., Keller, U., Hornung, C., Reichert, M., \& Martin, R. (2009). The cross-cultural generalizability of a new structural model of academic self-concept. Learning and Individual Differences, 19, 387-403. DOI: 10.1016/j.lindif.2008.11.008.

Byrne, B.M. (1996). Academic self-concept: Its structure, measurement, and relation to academic achievement. In B.A. Bracken (Ed.), Handbook of self-concept. Developmental, social, and clinical considerations (pp. 287-316). New York: Wiley.

Chiu, M.M., \& McBride-Chang, C. (2006). Gender, context, and reading: A comparison of students in 43 countries. Scientific Studies of Reading, 10, 331-362. DOI: 10.1207/s 15327xssr1004_1.

Cole, D.A., Martin, J.M., Peeke, L.A., Seroczynski, A.D., \& Fier, J. (1999). Children's overand underestimation of academic competence: A longitudinal study of gender differences, depression, and anxiety. Child Development, 70, 459-473. DOI: 10.1111/14678624.00033.

Crosnoe, R., Riegle-Crumb, C., \& Muller, C. (2007). Gender, self-perception, and academic problems in high school. Social Problems, 54, 118-138. DOI: 10.1525/sp.2007.54.1. 118.

Daniels, Z. (2008). Entwicklung schulischer Interessen im Jugendalter [Academic interests in adolescents]. Münster: Waxmann.

De Fraine, B., Van Damme, J., \& Onghena, P. (2007). A longitudinal analysis of gender differences in academic self-concept and language achievement: A multivariate multilevel latent growth approach. Contemporary Educational Psychology, 32, 132-150. DOI: 10.1016/j.cedpsych.2006.10.005.

Dewaele, J.-M. (2007). Predicting language learners' grades in L1, L2, L3 and L4: the effect of some psychological and sociocognitive variables. International Journal of Multilingualism, 4, 169-197. DOI: 10.2167/ijm080.0.

Dickhäuser, O., \& Meyer, W.-U. (2006). Gender differences in young children's math ability attributions. Psychology Science, 48, 3-16. URL: http://www.pabst-publishers.de/ psy- 
chology-science/1-2006/ps_1_2006_3-16.pdf.

Dijkstra, P., Kuyper, H., van der Werf, G., Buunk, A.P., \& van der Zee, Y.G. (2008). Social comparison in the classroom: A review. Review of Educational Research, 78, 828879. DOI: $10.3102 / 0034654308321210$.

DiPerna, J.C., Volpe, R.J., \& Elliott, S.N. (2001). A model of academic enablers and elementary reading/language arts achievement. School Psychology Review, 31, 298-312.

Dörnyei, Z., \& Clément, R. (2001). Motivational characteristics of learning different target languages: Results of a nationwide survey. In Z. Dörnyei, \& R. Schmidt (Eds.), Motivation and second language acquisition. Technical Report \#23 (pp. 399-432). Honululu, University of Hawai'i: Second Language Teaching and Curriculum Center.

Du, M. (2012). A study of the relationship between English self-concept and language learning strategies. Journal of Language Teaching and Research, 3, 508-517. DOI: 10.4304 /j1tr.3.3.508-517.

Durlak, J.A. (2009). How to select, calculate, and interpret effect sizes. Journal of Pediatric Psychology, 34, 917-928. DOI: 10.1093/jpepsy/jsp004.

Eccles, J.S., Jacobs, J.E., \& Harold, R.D. (1990). Gender role stereotypes, expectancy effects, and parents' socialization of gender differences. Journal of Social Issues, 46, 183-201. DOI: 10.1111/j.1540-4560.1990.tb01929.x.

Ehm, J.-H., Duzy, D., \& Hasselhorn, M. (2011). Das akademische Selbstkonzept bei Schulanfängern. Spielen Geschlecht und Migrationshintergrund eine Rolle? [Academic selfconcept in elementary school beginners. The impact of gender and migration background]. Frühe Bildung, 0, 37-45. DOI: 10.1026/2191-9186/a000008.

Else-Quest, N.M., Hyde, J.S., \& Linn, M.C. (2010). Cross-national patterns of gender differences in mathematics: A meta-analysis. Psychological Bulletin, 136, 103-127. DOI: 10.1037/a0018053.

Enders, C.K. (2010). Applied missing data analysis. New York: Guilford Press.

Faber, G. (2003). Analyse geschlechtsabhängiger Ausprägungen im rechtschreibspezifischen Selbstkonzept von Grundschulkindern [Gender differences in elementary students' spelling-specific self-concept]. Zeitschrift für Entwicklungspsychologie und Pädagogische Psychologie, 35, 208-211. DOI: 10.1026/0049-8637.35.4.208.

Faber, G. (2009). Die Erfassung kognitiv-motivationaler Lernermerkmale gegen Ende der gymnasialen Sekundarstufe I. Ergebnisse aus einem interdisziplinären Forschungsprojekt zur mündlichen Erzählkompetenz in Englisch [Measuring academic self-beliefs in secondary foreign language learners: Findings from an interdisciplinary study on EFL 
learners' oral narrative competencies]. Zeitschrift für Fremdsprachenforschung, 20, 179-212.

Faber, G. (2012a). Does gender moderate dimensional comparison effects in L1 and L2 selfconcepts of secondary foreign language learners? Electronic Journal of Research in Educational Psychology, 10, 1159-1182.

Faber, G. (2012b). Measuring self-perceptions of oral narrative competencies and anxiety in the EFL context. Electronic Journal of Research in Educational Psychology, 10, 1343-1382.

Faber, G. (2012c). Elementary school children's spelling-specific self-beliefs. Longitudinal analyses of their relations to academic achievement, school attitudes, and self-esteem. New York: Nova Science Publishers.

Faber, G., \& Billmann-Mahecha, E. (2012). Schulfachliche Leistungen und Selbsteinschätzungen in Abhängigkeit von Familiensprache und Geschlecht: Befunde aus einer Studie in dritten und vierten Grundschulklassen [An analysis of gender and ethnic differences in elementary third- and fourth-graders' academic achievement and selfconcept]. In F. Hellmich, S. Förster, \& F. Hoya (Hrsg.), Bedingungen des Lehrens und Lernens in der Grundschule. Bilanz und Perspektiven. Jahrbuch Grundschulforschung Band 16 (S. 271-274). Wiesbaden: Verlag für Sozialwissenschaften.

Faber, G., Tiedemann, J., \& Billmann-Mahecha, E. (2011). Selbstkonzept und Lernfreude in der Grundschulmathematik: Die Bedeutung von Migration und Geschlecht. Längsschnittliche Ergebnisse aus der Hannoverschen Grundschulstudie [Mathematics selfconcept and affective task value in elementary students: The impact of gender and migration background]. Heilpädagogische Forschung, 37, 127-143.

Frenzel, A., Pekrun, R., \& Goetz, T. (2007). Girls and mathematics - A "hopeless" issue? A control-value approach to gender differences in emotions toward mathematics. European Journal of Psychology of Education, 22, 497-514. DOI: 10.1007/BF03173468.

Frühauf, S. (2008). Bereichsspezifische Selbstkonzepte bei Grundschulkindern. Operationalisierung und Validierung eines hypothetischen Konstrukts [Subject-specific self-concepts in elementary school children. A validation approach]. Hamburg: Kovač.

Gambell, T.J., \& Hunter, D.M. (1999). Rethinking gender differences in literacy. Canadian Journal of Education, 24, 1-16. URL: http://www.jstor.org/stable/1585767.

Georgiou, S.N., Stavrinides, P., \& Kalavana, T. (2007). Is Victor better than Victoria at maths? Educational Psychology in Practice, 23, 329-342. DOI: 10.1080/0266736070 1660951. 
Hartig, J., \& Jude, N. (2008). Sprachkompetenzen von Mädchen und Jungen [Verbal competencies in girls and boys]. In DESI-Konsortium (Hrsg.), Unterricht und Kompetenzerwerb in Deutsch und Englisch. Ergebnisse der DESI-Studie (S. 202-207). Weinheim: Beltz.

Hattie, J.A.C. (2009). Visible learning. A synthesis of over 800 meta-analyses relating to achievement. London: Routledge.

Hattie, J., \& Marsh, H.W. (1996). Future directions in self-concept research. In B.A. Bracken (Ed.), Handbook of self-concept. Developmental, social, and clinical considerations (pp. 421-462). New York: Wiley.

Hay, I., Ashman, A.F., \& van Kraayenoord, C.E. (1998). The influence of gender, academic achievement and non-school factors upon pre-adolescent self-concept. Educational Psychology, 18, 461-470. DOI: 10.1080/0144341980180407.

Haynes, N.M., Hamilton-Lee, M., \& Comer, J.P. (1988). Differences in self-concept among high, average, and low achieving high school sophomores. Journal of Social Psychology, 128, 259-264. DOI: 10.1080/00224545.1988.9711370.

Hedges, L.V. (1982). Estimation of effect size from a series of independent experiments. Psychological Bulletin, 92, 490-499. DOI: 10.1037/0033-2909.92.2.490.

Heinzmann, S. (2009). "Girls are better at language learning than boys“: Do stereotypic beliefs about language learning contribute to girls' higher motivation to learn English in primary school? Bulletin Suisse de Linguistique Appliquée, 89, 19-36.

Helmke, A., Schrader, F.-W., Wagner, W., Nold, G., \& Schröder, K. (2008). Selbstkonzept und Motivation im Fach Englisch [Self-concept and motivation in learning English as a foreign language]. In DESI-Konsortium (Hrsg.), Unterricht und Kompetenzerwerb in Deutsch und Englisch. Ergebnisse der DESI-Studie (S. 244-257). Weinheim: Beltz.

Henry, A. (2009). Gender differences in compulsory school pupils' L2 self-concepts: A longitudinal study. System, 37, 177-193. DOI: 10.1016/j.system.2008.11.003.

Herbert, J., \& Stipek, D. (2005). The emergence of gender differences in children's perceptions of their academic performance. Applied Developmental Psychology, 26, 276295. DOI: 10.1016/j.appdev.2005.02.007.

Hergovich, A., Sirsch, U. \& Felinger, A. (2004). Gender differences in the self-concept of preadolescent children. School Psychology International, 25, 207-222. DOI: 10.1177/ 01430343043688.

Holder, M.C. (2005). Fähigkeitsselbstkonzept und Leistungsmotivation im Fremdsprachenunterricht [Competence beliefs and academic motivation in the EFL context]. Bern: 
Lang.

Holm, S. (1979). A simple sequentially rejective multiple test procedure. Scandinavian Journal of Statistics, 6(2), 65-70. URL: http://www.jstor.org/stable/4615733.

Jacobs, J. E., Lanza, S., Osgood, D., Eccles, J. S., \& Wigfield, A. (2002). Changes in children's self-competence and values: Gender and domain differences across grade one through twelve. Child Development, 73, 509-527. DOI: 10.1111/1467-8624.00421.

Kirk, R.E. (1982). Experimental design: Procedures for the behavioral sciences (2nd ed.). Belmont: Brooks/Cole Publishing.

Kiuru, N., Leskinen, E., Nurmi, J.-E., \& Salmelo-Aro, K. (2011). Depressive symptoms during adolescence: Do learning difficulties matter? International Journal of Behavioral Development, 35, 298-306. DOI: 10.1177/0165025410396764.

Köller, O., Zeinz, H., \& Trautwein, U. (2008). Class-average achievement, marks, and academic self-concept in German primary schools. In H.W. Marsh, R.G. Craven \& D.M. McInerney (Eds.), Self-processes, learning, and enabling human potential. Dynamic new approaches (pp. 331-352). Charlotte: Information Age Publishing.

Krätzschmar, M. (2010). Selbstkonzepte in altersgemischten Lerngruppen. Eine Längsschnittstudie mit Kontrollgruppen in der Sekundarstufe [Academic self-concepts in heterogeneous age courses at the secondary school level]. Münster: Waxmann.

Kuncel, N.R., Credé, M., \& Thomas, L.L. (2005). The validity of self-reported grade point averages, class ranks, and test scores: A meta-analysis and review of the literature. Review of Educational Research, 75, 63-82. DOI: 10.3102/00346543075001063.

Kurman, J. (2004). Gender, self-enhancement, and self-regulation of learning behaviors in junior high school. Sex Roles, 50, 725-735. DOI: 10.1023/B:SERS.0000027573.36376. 69.

Kurtz-Costes, B., Rowley, S.J., Harris-Britt, A., \& Woods, T.A. (2008). Gender stereotypes about mathematics and science and self-perceptions of ability in late childhood and early adolescence. Merrill-Palmer Quarterly, 54, 386-409. DOI: 10.1353/mpq.0.0001.

Lee, J., \& Shute, V.J. (2010). Personal and social-contextual factors in K-12 academic performance: An integrative perspective on student learning. Educational Psychologist, 45, 1-19. DOI: $10.1080 / 00461520.2010 .493471$.

Lehmann, R.H., Gänsfuß, R., \& Husfeldt V. (2011). LAU 9. Aspekte der Lernausgangslage und der Lernentwicklung - Klassenstufe 9 [An analysis of academic trajectories in secondary ninth-graders]. In Behörde für Schule und Berufsausbildung (Hrsg.), LAU - 
Aspekte der Lernausgangslage und der Lernentwicklung. Klassenstufen 5, 7 und 9 (S. 287-451). Münster: Waxmann.

Lehmann, R.H., Gänsfuß, R., \& Peek, R. (2011). LAU 7. Aspekte der Lernausgangslage und der Lernentwicklung - Klassenstufe 7 [An analysis of academic trajectories in secondary seventh-graders]. In Behörde für Schule und Berufsausbildung (Hrsg.), LAU Aspekte der Lernausgangslage und der Lernentwicklung. Klassenstufen 5, 7 und 9 (S. 121-285). Münster: Waxmann.

Lindberg, S., Linkersdörfer, J., Ehm, J.-H., Hasselhorn, M., \& Lonnemann, J. (2013). Gender differences in children's math self-concept in the first years of elementary school. Journal of Education and Learning, 2(3), 1-8. DOI: 10.5539/jel.v2n3p1.

MacIntyre, P.D., Baker, S.C., Clément, R., \& Donovan, L.A. (2002). Sex and age effects on willingness to communicate, anxiety, perceived competence, and L2 motivation among junior high school French immersion students. Language Learning, 52, 537564. DOI: 10.1111/1467-9922.00226.

Marsh, H.W. (1989). Sex differences in the development of verbal and mathematics constructs: The high school and beyond study. American Educational Research Journal, 26, 191-225. DOI: 10.3102/00028312026002191.

Marsh, H.W., \& O’Mara, A.J. (2008). Self-concept is as multidisciplinary as it is multidimensional. A review of theory, measurement, and practice in self-concept research. In H.W. Marsh, R.G. Craven \& D.M. McInerney (Eds.), Self-processes, learning, and enabling human potential. Dynamic new approaches (pp. 87-115). Charlotte: Information Age Publishing.

Marsh, H.W., \& Yeung, A.S. (1998). Longitudinal structural equation models of academic self-concept and achievement: Gender differences in the development of math and English constructs. American Educational Research Journal, 35, 705-738. DOI: 10.3 $102 / 00028312035004705$.

Martin, A. (2010). Building classroom success. Eliminating academic fear and failure. London: Continuum International Publishing Group.

Meece, J.L., Glienke, B.B. \& Askew, K. (2009). Gender and motivation. In K.R. Wentzel \& A. Wigfield (Eds.), Handbook of motivation at school (pp. 411-431). New York: Routledge.

Meelissen, M., \& Luyten, H. (2008). The Dutch gender gap in mathematics: Small for achievement, substantial for beliefs and attitudes. Studies in Educational Evaluation, 34, 82-93. DOI: 10.1016/j.stueduc.2008.04. 
Möller, J., \& Pohlmann, B. (2010). Achievement differences and self-concept differences: Stronger associations for above or below average students? British Journal of Educational Psychology, 80, 435-450. DOI: 10.1348/000709909X485234.

Möller, J., Pohlmann, B., Köller, O., \& Marsh, H.W. (2009). A meta-analytic path analysis of the internal/external frame of reference model of academic achievement and academic self-concept. Review of Educational Research, 79, 1129-1167. DOI: 10.3102/003465 4309337522.

Möller, J., Streblow, L., Pohlmann, B., \& Köller, O. (2006). An extension to the internal/external frame of reference model to two verbal and numerical domains. European Journal of Psychology of Education, 21, 467-487. DOI: 10.1007/BF03173515.

Mullis, I.V.S., Martin, M.O., Goldberg, A.L., \& Stemler, S.E. (2000). Gender differences in achievement. IEA's Third International Mathematics and Science Study (TIMSS). Chestnut Hill: Boston College.

Nikolova, R. (2011). Englischleistungen und Einstellungen zum Englischunterricht [Achievement and attitudes in the EFL context]. In U. Vieluf, S. Ivanov \& R. Nikolova (Hrsg.), KESS 10/11 - Kompetenzen und Einstellungen von Schülerinnen und Schülern an Hamburger Schulen am Ende der Sekundarstufe I und zu Beginn der gymnasialen Oberstufe (S. 121-157). Münster: Waxmann.

Nikolova, R., \& Ivanov, S. (2010). Englischleistungen [Secondary students' English proficiency]. In W. Bos \& C. Gröhlich (Hrsg.), KESS 8 - Kompetenzen und Einstellungen von Schülerinnen und Schülern am Ende der Jahrgangsstufe 8 (S. 41-59). Münster: Waxmann.

Papadakis, A.A., Prince, R.P., Jones, N.P., \& Strauman, T.J. (2006). Self-regulation, rumination, and vulnerability to depression in adolescent girls. Development and Psychopathology, 18, 815-829. DOI: 10.10170S095457940606060408.

Pintrich, P.R. (2003). Motivation and classroom learning. In W.M. Reybolds, G.E. Miller \& I.B. Weiner (Eds.), Handbook of psychology. Volume 7: Educational psychology (pp. 103-122). Hoboken: Wiley.

Pomerantz, E.M., Altermatt, E.R., \& Saxon, J.L. (2002). Making the grade but feeling distressed: Gender differences in academic performance and internal distress. Journal of Educational Psychology, 94, 396-404. DOI: 10.1037/0022-0663.94.2.396.

Räty, H., Kasanen, K., \& Kärkkäinen, R. (2006). School subjects as social categorisations. Social Psychology of Education, 9, 5-25. DOI: 10.1007/s11218-005-2439-6.

Rao, N., Moely, B.E. \& Sachs, J. (2000). Motivational beliefs, study strategies, and mathema- 
tics attainment in high- and low-achieving Chinese secondary school students. Contemporary Educational Psychology, 25, 287-316. DOI: 10.1006/ceps.1999.1003.

Rijavec, M., \& Brdar, I. (1997). Coping with school failure: Development of the school failure coping scale. European Journal of Psychology of Education, 12, 37-49. DOI: 10.1007 /BF03172868.

Rinn, A.N., McQueen, K.S., Clark, G.L. \& Rumsey, J.L. (2008). Gender differences in gifted adolescents' math/verbal self-concepts and math/verbal achievement: Implications for the STEM fields. Journal for the Education of the Gifted, 32, 34-53. URL: http:// escholarship.bc.edu/education/tecplus/vol6/iss4/art1.

Rost, D.H., Sparfeldt, J.R., \& Schilling, S.R. (2007). DISK-Gitter mit SKSLF-8. Differentielles Selbstkonzept-Gitter mit Skala zur Erfassung des Selbstkonzepts schulischer Leistungen und Fähigkeiten [The self-concept grid: A questionnaire for measuring facets of academic self-concept]. Göttingen: Hogrefe.

Rouxel, G. (2000). Cognitive-affective determinants of performance in mathematics and verbal domains: gender differences. Learning and Individual Differences, 12, 287-310. DOI: $10.1016 / \mathrm{S} 1041-6080(01) 00041-3$.

Rusillo, M.T.C., \& Arias, P.F.C. (2004). Gender differences in academic motivation of secondary school students. Electronic Journal of Resarch in Educational Psychology, 2, $97-$ 112.

Rustemeyer, R., \& Fischer, N. (2005). Sex- and age-related differences in mathematics. Psychological Reports, 97, 183-194. DOI: 10.2466/pr0.97.1.183-194.

Ruxton, G.D. (2006). The unequal variance t-test is an underused alternative to Student's ttest and the Mann-Whitney U test. Behavioral Ecology, 17, 688-690. DOI: 10.1093/ behecolark016.

Sáinz, M., \& Eccles, J. (2012). Self-concept of computer and math ability: Gender implications across time and within ITC studies. Journal of Vocational Behavior, 80, 486499. DOI: 10.1016/j.jvb.2011.08.0.

Schilling, S.R., Sparfeldt, J.R., \& Rost, D.H. (2006). Facetten des schulischen Selbstkonzepts. Welchen Unterschied macht das Geschlecht? [Does gender make a difference in students' academic self-concepts?] Zeitschrift für Pädagogische Psychologie, 20, 9-18. DOI: 10.1024/1010-0652.20.1.9.

Seaton, M., Marsh, H.W., \& Craven, R.G. (2009). Earning its place as a pan-human theory: Universality of the big-fish-little-pond effect across 41 culturally and economically di- 
verse countries. Journal of Educational Psychology, 101, 403-419. DOI: 10.1037/a00 13838.

Skaalvik, E.M. \& Skaalvik, S. (2002). Internal and external frames of reference for academic self-concept. Educational Psychologist, 37, 233-244. DOI: 10.1207/S15326985EP37 04_3.

Skaalvik, S., \& Skaalvik, E.M. (2004). Gender differences in math and verbal self-concept, performance expectations, and motivation. Sex Roles, 50, 241-252. DOI: 10.1023/B: SERS.0000015555.40976.e6.

Sparks, R.L. (2012). Individual differences in L2 learning and long-term L1-L2 relationships. Language Learning, 62 (Suppl. 2), 5-27. DOI: 10.1111/j.1467-9922.2012.00704.x.

Steffens, M.C., \& Jelenec, P. (2011). Separating implicit gender stereotypes regarding math and language: Implicit ability stereotypes are self-serving for boys and men, but not for girls and women. Sex Roles, 64, 324-335. DOI: 10.1007/s11199-010-9924-x.

Steinmayr, R., \& Spinath, B. (2008). Sex differences in school achievement: What are the roles of personality and achievement motivation? European Journal of Personality, 22, 185-209. DOI: 10.1002/per.676.

Stetsenko, A., Little, T.D., Gordeeva, T., Grasshof, M., \& Oettingen, G. (2000). Gender effects in children's beliefs about school performance: A cross-cultural study. Child Development, 71, 517-527. DOI: 10.1111/1467-8624.00161.

Stipek, D.J., \& Gralinski, J.H. (1991). Gender differences in children's achievement-related beliefs and emotional responses to success and failure in mathematics. Journal of Educational Psychology, 83, 361-371. DOI: 10.1037/0022-0663.83.3.361.

Tiedemann, J. (2000). Parents' gender stereotypes and teachers' beliefs as predictors of children's concept of their mathematical ability in elementary school. Journal of Educational Psychology, 92, 144-151. DOI: 10.1037/0022-0663.92.1.144.

Tiedemann, J., \& Faber, G. (1995). Mädchen im Mathematikunterricht: Selbstkonzept und Kausalattributionen im Grundschulalter [Gender differences in mathematics self-concept and causal attributions]. Zeitschrift für Entwicklungspsychologie und Pädagogische Psychologie, 27, 61-71.

Treutlein, A., \& Schöler, H. (2009). Zum Einfluss der schulischen Lernumwelt auf die Schulleistung [School environmental effects on academic achievement]. In J. Roos \& H. Schöler (Hrsg.), Entwicklung des Schriftspracherwerbs in der Grundschule. Längsschnittanalyse zweier Kohorten über die Grundschulzeit (S. 109-143). Wiesbaden: Verlag für Sozialwissenschaften. 
Valentine, J.C., DuBois, D.L., \& Cooper, H. (2004). The relation between self-beliefs and academic achievement: A meta-analytic review. Educational Psychologist, 39, 111133. DOI: 10.1207/s15326985ep3902_3.

Van Gelderen, A., Schoonen, R., Stoel, R.D., de Glopper, K., \& Hulstijn, J. (2007). Development of adolescent reading comprehension in language 1 and language 2: A longitudinal analysis of constituent components. Journal of Educational Psychology, 99, 477491. DOI: 10.1037/0022-0663.99.3.477.

Watt, H.M.G. (2004). Development of adolescents' self-perceptions, values, and task perceptions according to gender and domain in 7th- through 11th-Grade Australian students. Child Development, 75, 1556-1574. DOI: 10.1111/j.1467-8624.2004.00757.x.

Wigfield, A., Eccles, J.S., Schiefele, U., Roeser, R.W., \& Davis-Kean, P. (2006). Development of achievement motivation. In N. Eisenberg (Ed.), Handbook of child psychology. Volume 3: Social, emotional, and personality development (6th ed., pp. 933-1002). New York: Wiley.

Wilgenbusch, T., \& Merrell, K.W. (1999). Gender differences in self-concept among children and adolescents: A meta-analysis of multidimensional studies. School Psychology Quarterly, 14, 101-120. DOI: 10.1037/h0089000.

Williams, M., Burden, R., \& Lanvers, U. (2002). 'French is the language of love and stuff': students perceptions of issues related to motivation in learning a foreign language. British Educational Research Journal, 28, 503-528. DOI: 10.1080/014119202200000 5805 .

Winkelmann, H., \& Groeneveld, I. (2010). Geschlechterdisparitäten [Gender differences in verbal competencies]. In O. Köller, M. Knigge \& B. Tesch (Hrsg.), Sprachliche Kompetenzen im Ländervergleich (S. 177-184). Münster: Waxmann.

Zaunbauer, A.C.M., Retelsdorf, J., \& Möller, J. (2009). Die Vorhersage von Englischleistungen am Anfang der Sekundarstufe [Prediction of secondary students' achievement in English as a foreign language]. Zeitschrift für Entwicklungspsychologie und Pädagogische Psychologie, 41, 153-164. DOI: 10.1026/0049-8637.41.3.153.

Ziegler, A., \& Stöger, H. (2002). Motivationale Ziele im Mathematikunterricht von MittelstufenschülerInnen am Gymnasium [Motivational goals of high school students in mathematics instruction]. Empirische Pädagogik, 16, 57-78.

Zimmerman, B.J., \& Cleary, T.J. (2009). Motives to self-regulate learning. A social-cognitive account. In K.R. Wentzel \& A. Wigfield (Eds.), Handbook of motivation at school (pp. 247-264). New York: Routledge. 